\title{
Estevanico's Legacy: Insights into Colonial Latin American Studies from Postcolonial Africa
}

(c) Rolena Adorno

Yale University

E-mail - rolena.adorno@yale.edu

\section{Transatlantic and Tri-Continental}

Estevanico's legacy is nothing if not ambiguous. So was his personal experience. He was a black African slave-Christianized but Arabicspeaking-who helped Álvar Núñez Cabeza de Vaca and two other Castilians of the ill-fated 1527 Pánfilo de Narváez expedition survive nearly eight years of hardship in the Texas wilderness. After the men's successful return to Spanish-held territory, Estevanico was resold into slavery and died violently somewhere in today's New Mexico [1]. In his years with Cabeza de Vaca he imposed the authority of white European men on native Amerindian communities on a continent to which neither he or the white men, whose bidding he was forced to do, belonged. From his native North Africa to Castile to the Caribbean to eastern coastal Texas to Mexico-Tenochtitlán, and ultimately to what was probably the land of the Zuni in today's New Mexico, Estevanico trudged a trail of forced migration common to the colonized subjects of imperial Spain. Today, he is heralded as having been "the first black man in North America." He has been thus featured in novels written for adults and juvenile fiction [2]. In a 1994 reference work called Historic World Leaders (256), published by Gale Research in Detroit, the entry for "Estévan" describes him as a "black explorer, who helped open what would become the southwestern United States to Spanish settlement."

This description serves as a springboard to broach one of the questions that Professor Martínez-San Miguel and her colleagues have asked us to consider: "How can we propose comparative studies on transatlantic cultural relations that do not replicate Eurocentric models of understanding the colonial subjects?" Clearly, the Gale Research project did not meet that challenge. While intending to perform the laudable task of including the excluded actors of history into textbook narratives thereof, Gale's writers simply reproduced the master narrative, inserting Estevanico into a category, "heroic black explorer," that is misleading if not preposterous under the conditions of slavery that impinged upon him--even when he and the three white men he accompanied were hundreds of miles away from, and 
presumably lost forever to, "Spanish civilization." "How," our Rutgers hosts have asked, "can we transcend national paradigms to foster comparative studies that re-establish the internal contacts between metropolitan centers and colonial territories?" How can we articulate broader perspectives on colonialism that are also more representative of the specific objects of analysis that we seek to examine?

My first clues in trying to answer these questions did not come from Estevanico, who, of course, was never allowed to speak for himself. As a slave, he was prohibited from offering legally certifiable testimony about his and his companions' seven-and-a-half year captivity in North America. Nevertheless, his experience was central to the dynamic that I want to discuss. He was a native of Azamour in the province of Doukkala in the kingdom of Morocco. He was sold into slavery at an early age and transported (probably) to Seville, where he was purchased by Andrés Dorantes de Carranza before beginning in 1527 his long transatlantic and later transcontinental odysseys that would be followed by his violent death in 1539 (Adorno and Pautz 2: 414415). His single case epitomizes the circumstances and globalizing reach of early modern colonialism, and it renders a regional or even national purview on colonialism altogether too limited.

If in the sixteenth century Estevanico was enslaved on three continents and could not speak for himself, a twentieth-century Ghanean literary critic, Josephat Bekunuru Kubayanda (1944-1991), who was educated on the same three continents, has spoken for both of them. Kubayanda, too soon deceased, wrote comparatively on Latin American and Caribbean as well as African and African Diaspora literatures. I cite here his 1990 essay, "On Colonial/Imperial Discourse and Contemporary Critical Theory." As he undertook a review of the "contribution of Third World critics and minorities in the Western cultural setup," Kubayanda (4-5) spoke of African critics' resistance to theories "devised almost exclusively from a certain privileged ideological or power position . . . and from a very small number of eurocentric texts." He cautioned that critical theory had the "potential not only to exclude, or marginalize, but to lie about its universality."

Among the authors Kubayanda considered, he characterized Albert Memmi's The Colonizer and the Colonized, originally published in French in 1957 under the title Portrait du Colonisé précédé du Portrait du Colonisateur, as the major postcolonialist contribution of the end of the 1950s. Kubayanda (10) judged Memmi's work to have been unjustly overlooked in postcolonialist discussions, even though it had been the "first African work in modern times to portray so thoroughly the colonizer and the colonized and simultaneously, to examine the ambiguous relationship between them." Memmi's essay had 
audiences among Africans, Latin Americans, Japanese, and African Americans, as reflected by its numerous translations: Japanese (1959), English (two U.S. editions, 1965 and 1967, respectively), Portuguese $(1967,1974)$, Spanish $(1969,1971)$, Basque (1974), and Italian (1979) (Memmi 158). Despite the work's international success, Memmi (xi) faulted the European Left--his friend and prologuist JeanPaul Sartre being a notable exception--for underestimating the national aspect of colonial liberation at the time. Kubayanda (11) agreed, insofar as "the support of the European Left for the anticolonial movements in Africa during the 1950s was driven toward achieving an international anti-imperialist agenda and not directly toward fostering the plans of particular nations."

Today, long after the euphoric hopes for the effectiveness of African national liberation have been dashed, Susan Gilson Miller's (in Memmi $158,164)$ "Afterword" to the current edition of Memmi's work points to its datedness as an artifact no longer "seized upon by leaders of a generation in revolt as a blueprint for action." She cites Memmi's (later-regretted) exclusion of "women as personalities in the colonialist drama" as one of its notable omissions. She also argues that Memmi's position on language is out of date, stating that his idea that mastering the language of the colonizer produced "cultural crisis" for the colonized was simply "no longer an issue" (Miller in Memmi 164-165). I strongly disagree [3]. In fact, the issue of language and the position of the colonized writer in Memmi's work has, I want to argue, great relevance for postcolonial studies broadly and particularly for those concerned with colonial Latin America.

To discuss the possibility of the productivity of postcolonial African writings such as Memmi's for colonial Latin American studies, I turn to my own experience with the pedagogical challenge of studying Spanish colonial-era writings and reflecting on colonialism with today's university students. Parenthetically (but not paradoxically), I note that teaching, even more than scholarly investigation, urges us to undertake cross-cultural comparative studies in order to test variants of theories of colonialism (in this case, intellectual life under colonialism) in diverse cultural or cultural historical settings and/or, conversely, to elucidate the unique or common traits of any particular cultural or cultural historical historical instance. The point I wish to make is that Memmi's work made it possible for my students to conceptualize and imagine more vividly the often subtle burdens of intellectual life under colonialism. I take this single case as an example to suggest how we can propose, as our Rutgers hosts have urged us, to conceptualize "comparative studies on transatlantic cultural relations" that are productive precisely because they "do not replicate Euro-centric models of understanding colonial subjectivity." 
We seek formulations, in other words, that are revealing because they enable the discovery of significant differences as well as overarching commonalities.

\section{The Colonial Situation and Linguistic Dualism}

"The colonial situation": In 1957 Memmi defined living under (or, alternatively, off the fruits of) colonialism as a "situation," as a set of objective social and historical circumstances. In doing so, he rejected the hold-over notions that colonialism was a "natural" system and that those subjugated by it were simply living in accordance with their biological nature: "What is the colonized, in actual fact? I believe neither in metaphysical essence nor in psychological essence. One can describe the colonized at present." (Memmi 152-153). One can define a colonized subject, that is, by his or her circumstances. If one can speak at all of the "inadequacy" of the colonized as unassimilated or unassimilable, Memmi (93) wrote, it was "born of a situation and of the will of the colonizer;" it was "only that and not some congenital inability to assume a role in history." He (xvi) insisted that "a man is a product of his objective situation" and, among the situations of the colonized, he named as its most serious consequence being "removed from history and from the community."

Memmi further described the colonial situation, as it pertains to the colonized, in these terms: Carrying the burden of history, the colonized is always its object, never its subject; the memory and history he is assigned are those of the colonizer, not those of his own people (Memmi 91-92, 95). Oppressed by the laws under which he lives, the colonized lacks the rights of citizenship and is denied any participation in the governance of even community affairs, and so he takes refuge in the traditional culture of family and/or religion. If saved from illiteracy, he falls into a linguistic dualism (Memmi 99-101, 105, 106).

This "linguistic dualism" constitutes one of the most productive dimensions of Memmi's concept of the colonial situation for exploring the writings of colonial Latin America. Linguistic dualism's colonial form is "colonial bilingualism," which "cannot be compared to just any linguistic dualism." Insofar as having two languages means participation in two psychical and cultural realms, the problem in colonial bilingualism is that "the two worlds symbolized and conveyed by the two tongues are in conflict." It is "neither a purely bilingual situation in which an indigenous tongue coexists with a purist's language (both belonging to the same world of feeling), nor a simple 
polyglot richness benefiting from an extra but relatively neuter alphabet." It is instead a "linguistic drama" (Memmi 107-108).

If linguistic ambiguity is the symbol as well as one of the major causes of cultural ambiguity, the position of the colonized writer is one of the most perfect examples of this "linguistic drama." For whom shall he or she write? For his or her own people, who may not read any language at all, or for the bourgeoisie and the scholars, who read only the colonizer's language? The paradox arises from the need to write in the colonizer's language in order to claim the dignity and legitimacy of one's own. The result: "The colonized writer is condemned to live his renunciations to the bitter end" (Memmi 108, 110-111).

The rawness of Memmi's account is heightened by the fact that he personally shared in this linguistic and cultural dilemma: "I was a sort of half-breed of colonization," he (xvi) wrote, "understanding everyone because I belonged completely to no one."

Memmi's (xiv) portrait of the colonized, he said, was his own. While "treated as a second-class citizen, deprived of political rights, refused admission to most civil service departments" as a Tunisian, he was nevertheless a Jew, and he wrote about the Jewish community of Tunisia as follows:

They were undeniably 'natives,' as they were then called, as near as possible to the Moslems in poverty, language, sensibilities, customs, taste in music, odors and cooking. However, unlike the Moslems, they passionately endeavored to identify themselves with the French. To them the West was the paragon of all civilization, all culture. The Jew turned his back happily on the East. He chose the French language, dressed in the Italian style and joyfully adopted every idiosyncrasy of the Europeans. (This, by the way, is what all colonized try to do before they pass on to the stage of revolt).

In this apparently descriptive assessment of his own ethnic community, Memmi implicitly raised many of the pertinent issues regarding external and self-identification. The immediacy of these questions as Memmi posed them created a threshold, easily crossed, that allowed my students entrance into the realm populated by the creole (criollo), mestizo, and Indian voices of the Latin American past. Issues of language, colonial bilingualism, and cultural complexity are all pertinent. Memmi's "I was a sort of half-breed of colonization, understanding everyone because I belonged completely to no one" applies as well to writers from early colonial Mexico and Peru, such as 
the Peruvians El Inca Garcilaso de la Vega (1539-1616) and Felipe Guaman Poma de Ayala (1530s-c. 1616).

Hence, reading Memmi gave my undergraduate course on colonial texts and postcolonial theory four tools of great use. The first was Memmi's help in moving readers beyond the common binary opposition of colonizer and colonized so as to be able to speak to the mutual dependency and ambiguity of colonial relationships. The second was that his essay made it possible to transcend the moment of the horrors of military conquest and help the students contemplate with interest all that followed the shocks of violent encounter and swift subjugation. It was Memmi, after all, who focused attention on the phenomenon of colonialism as "the colonial situation," which is a term that was later taken up in Latin American Colonial studies, where it remains a productive category of analysis. Third, Memmi draws our attention to the writing subject as a mediating and highly mediated position. After Memmi, one picks up the works of El Inca Garcilaso or Felipe Guaman Poma not for the usual tale of conquest they tell, but with an acute awareness of the writer and the complex positioning of the writing subject [4]. Fourth, even though Memmi's work is dated, being more than forty years old, it nevertheless requires us to confront the currency of the colonial situation.

By presenting to students the riveting essay of Memmi, who wrote about colonialism in the direct and unambiguous way that El Inca Garcilaso himself never would or could, and by reading with the students selections of postcolonial theory, my aim was to help them see the modernity of narrative texts that otherwise would seem hopelessly remote in time and experience. The result was that Garcilaso's work was remarkably accessible to undergraduate readers. His intense focus on language, from his "Notes on the General Language of the Indians of Peru" ["Advertencias sobre la lengua general de los indios del Perú"] through his long digressions on the problems of translation and communication at the Cajamarca encounter between the Inca prince Atahualpa and the Dominican friar Vicente de Valverde, produced extraordinary class interest and discussion.

Garcilaso's (3: 49-50, 52-53a) account of the initial meeting of Pizarro and his army with the Inca Atahualpa and his large entourage includes Garcilaso's unlikely defense of the coastal Indian Felipillo in his impossible task of interpreting highland Quechua and Spanish. It also takes up Garcilaso's ruminations on what might actually have happened in the "conversation" between Atahualpa and Valverde. Garcilaso's conclusion of the episode, which narrates the massacre of some three thousand persons in the plaza in two stark, crisp 
sentences, focuses attention precisely back onto the linguistic encounter that preceded or provoked it. Reading this episode with Memmi's concept of "colonial biligualism" in mind, the students appreciated the dilemma inherent in Garcilaso's discussion of Felipillo's role and burden in the confrontation of the friar and the Inca. They interrogated this dilemma even more in their reading of Garcilaso's reflections on the prerogatives and prejudices regarding language use in Peru in his own day.

Thanks to Memmi's essay, the students were increasingly attentive to what they came to call Garcilaso's "double consciousness." Thanks especially to Memmi's provocative "I belonged completely to no one," they could grasp the similarity of the principle of intermediacy at work in both Garcilaso's and Memmi's experience as intellectuals.

Acknowledging the enormous gulf that existed between being a Jew in French colonial Tunisia in the 1950s and being an Inca in rural Andalusia in the 1590s, the students could grapple with the identity of both as belonging to an elite within the colonized group, which distanced them both from the unambiguously colonized and would forever hold them aloof from the traditional elite of the colonizer. It was the reading of Memmi, and particularly of passages like the long one cited above, that made it possible to "shake loose" or "shake out" some of the less obvious principles of El Inca Garcilaso's subject positions.

Felipe Guaman Poma's Nueva corónica y buen gobierno account of the Spanish conquest of Peru brought new challenges. The students were more immediately and more acutely aware of the problems of "colonial bilingualism" in Guaman Poma than in El Inca Garcilaso because of the structural difficulties of the Huamanga author's grammatically incorrect Spanish prose, which was formulated on the basis of his native Quechua phonology, morphology, and syntax [5]. Guaman Poma's extraordinary drawings brought other reflections as the students queried the techniques of his art, sought to examine its antecedents, and found in his self-portraits in European dress the elements of complex, colonial self-identification [6]. They read once again, in Guaman Poma's pictorial and prose texts, the episode of Atahualpa's meeting with the Spanish conquistadors at Cajamarca, and they leapt into a discussion of how and why it was interpreted differently than in El Inca Garcilaso's work. Overall, they seemed to have two principal interests: in Guaman Poma they could see clearly the generic hybridity or diversity of the work and, reading about the Cajamarca encounter for a second time, they moved away from the predictable (but generally fruitless) consideration of "what really happened" on that November afternoon in 1532. They focused instead on the larger issue of why this seemingly insignificant action in a 
larger, cataclysmic event was dwelt upon and reinterpreted time after time by writers a century and beyond that fateful day.

Together, we began to hammer out our own definitions of "postcolonial discourse" as we found it realized in El Inca Garcilaso and Guaman Poma. In both cases, the students understood that generic diversity was common, and we decided that this generic variety or instability might be symptomatic of that linguistic and cultural ambiguity that in Memmi's analysis plagued the colonized writer. We marked generic diversity as practiced by colonial writers, and singlegenre descriptions of their works as professed by them, to be phenomena that we would investigate and challenge in reading other "postcolonial" writings of the Spanish American colonial period.

Regarding the historical issue of "what really happened," the discussion quickly moved to the consensus that the postcolonial Garcilaso and Guaman Poma were not interested in historicity in the conventional sense. Both men knew perfectly well what had happened: military conquest was achieved and Spanish colonial domination imposed. "What happened" was not in doubt. Yet what was still open to debate was the rationality or irrationality, the legitimacy or illegitimacy, of all that had taken place. Seen in this light, the fate of Fray Vicente de Valverde's sacred book--whether it fell out of Atahualpa's lap onto the ground accidentally, as Garcilaso insisted, or whether the Inca prince threw it violently to the ground in rejection, as Guaman Poma declared--whatever had happened did not justify the violent massacre of unarmed soldiers and the live burial of innocent women and children crushed by falling walls that had encircled the plaza. At stake was the idea, as the students understood it, that the book--the sacred book, the book of authority--was manipulated and used in Hispanist history-writing to explain an illegitimate act of wanton violence. It was this awareness, my young interlocutors insisted, that El Inca Garcilaso and Guaman Poma articulated through their representations of the book in their respective, indirect and direct, condemnations of the events at Cajamarca.

\section{Colonialism and the Book}

The book stands at the heart of the colonial relationship. Essays like Homi Bhabha's "Signs Taken for Wonders" and Sabine MacCormack's "Atahualpa and the Book" make the point, respectively, for British colonialism in the nineteenth century and Spanish colonialism in the sixteenth. Antonio Cornejo-Polar's "Voz y letra en el 'dialógo' de Cajamarca," the brilliant first chapter of his Escribir en el aire, has the longest reach, charting the representation of the colonial 
book and Atahualpa's death all the way from the accounts of Spanish chronicles and indigenous writings in the sixteenth century through today's popular festivals in the Andean sierra, which Luis Millones has studied so effectively in Actores de altura. The originality and pertinence of Cornejo-Polar's argument is strengthened by recalling Memmi's insights about languages and, therefore, about cultures in antagonistic conflict. Cornejo-Polar (70) writes that these dramatized, improvised Andean highland performances straddle the divide that exists between the linguistic and cultural worlds of Quechua and Spanish, and between orality and writing. $\mathrm{He}(88-89)$ concludes that the actual object of analysis ought to be, in fact, the intersection of the contradictions between discordant rationalities of language, culture, and, ultimately, history, that are mutually incompatible. He (48) suggests that the initial triumph of the letter and the book at Cajamarca meant, concomitantly, the first "defeat of the voice in the Andes."

Signifier of colonial desire and discipline, "measure of mimesis and mode of civil authority and order," as Bhabha $(29,32)$ calls it, the book always seems to be at the center of the quintessential colonial encounter. He suggests what has also always been true, namely, that alongside the sacred book is the secular book. I learned this, years before his death, from Joe Kubayanda. The recollection gives me the opportunity to tell the anecdote that stimulated me to think about colonial Latin America through the lens of writers from postcolonial Africa. Kubayanda told me that what "the book" meant to his forebears was, simply put, colonialism. In the oral traditions of his family, he said, he recalled being told that when the British colonialists arrived, a uniformed colonial officer walked into the Kubayandas' ancestral village, opened a book, and read out the names of all the villagers, including those of Joe's elders. It was the census book and that, said Joe, was his family's introduction to colonialism: the assignment of duties and the assessment of taxes. All in all, it was the imposition by outsiders of responsibilities, for all of which one was held accountable because one's name was already written in a book.

It is revealing that many centuries earlier, in 1570, and on another continent, in highland Peru, one of the last living members of the Inca dynasty, Titu Cussi Yupanqui (4), recalled a similar phenomenon. He explained to the Spanish priest who was transcribing and translating his account of the Spanish invasion to which he had been an eyewitness: "And even we have seen with our own eyes how the Spaniards speak with their white sheets and name some of us by our own names, without us even telling them, just by looking at the sheet they have in front of them." ["Y aun nosotros los avemos visto por nuestros ojos a solas hablar en paños blancos y nombrar a algunos 
de nosotros por nuestros nonbres syn se lo dezir naidie, nomas de por mirar al paño que tienen delante."]

Reaching back in time, it does not seem an incommensurable distance from the census book that Joe Kubayanda's forebears remembered in Ghana, back to the ones that Titu Cussi Yupanqui recalled in Vilcabamba, and, further back still, to the sacred book that had been lost in the blood and dust of Cajamarca and that would be written about by El Inca Garcilaso and Guaman Poma decades--and by many others, centuries--afterward. The historical and cultural differences involved in these spatial-temporal leaps are enormous, but the events and processes that distinguish them are, at the same time, submitted to principles and techniques of interpretation or "sensemaking" that are interestingly similar.

These points of interpretive contact allow us to set up productive juxtapositions that do not wrongly assert cultural historical similarities where none exist, but that, rather, help us to "jog loose" the revealing detail in its uniqueness and specificity. In this light, it is not the "sameness" of the colonial Ghanean census book and its colonial Spanish forebear that is of interest; neither is it, per se, the event of their respective historical appearances. The pertinent factor is that the interpreters of the events, in both cases the colonized witnesses to it, grasped the book's strangeness and therefore its significance. Whether this was done immediately, during the historical event, or later, in reflective interpretation, matters not. It is only the latter site to which we can lay claim.

In this regard, I am not suggesting that the Kubayanda anecdote or the Bhabha essay (or any other postcolonial writing) should act as a kind of template, telling us to "see certain things" in colonial writings from other times and places. On the contrary, the postcolonial speculation, productively understood, merely invites us to ask questions other than those we might customarily have been asking within our familiar academic and disciplinary traditions of often limited protocols. As a "revealing detail," Titu Cussi's reference to the Spaniards' "white sheets" is not of interest because it was an action that was repeatable and repeated in the long history of colonialism but because, uniquely in Titu Cussi's circumstances, it produced a certain result: his timely and timeless account of the conduct of the Spanish invasion.

It does not seem coincidental, as he dictated in Quechua his oral account to a Spanish priest, that he reflected on foreigners' strange and powerful new medium. The connection between his observation about the "white sheets" and his own act of "writing" can be seen as 
causal in two senses: first, having seen the "white sheets" at work must have compelled him to use the same medium to make his own performed and vanishing words last; second, citing the power of the Spaniards' written words as he dictated his own, the subject Titu Cussi was not simply recalling an event but calling into play that event's potency for permanence now in his own behalf. Titu Cussi's act of dictating his account subverted, in 1570, the 1532 event described by Cornejo-Polar as "the defeat of the voice in the Andes." My point here is that, once made, the broad, trans-cultural historical comparison can be jettisoned in order to focus on the internal intricacies of the object which, without that comparison, would not be as fully and productively interrogated.

\section{Estevanico's Legacy}

To answer the question posed by our Rutgers hosts, I am convinced that by careful reading we can transcend national paradigms to foster comparative studies that re-establish the internal points of contact and the similarities of conduct that exist between metropolitan centers and colonial territories in different times and places. And I also believe, as in the demonstration about Titu Cussi Yupanqui's narrative, above, that we can then return to the specific object of analysis more productively. In this regard, the tri-continental, transatlantic experience of Estevanico, now taken as a critical category, is unambiguously illuminating. Just as his life extended beyond the acquaintance of a single region and far beyond a single continent, and just as his experience showed that a single pair of languages or a single pair of cultures was insufficient to describe and contain whatever one might seek to imagine or write about him, his legacy to colonial Latin American studies is the invitation, or the requirement, to think more broadly: historically, along cross-Atlantic lines, theoretically, into postcolonial formulations, and always beyond the binary opposition. The value of doing so is to enlarge the range of questions and insights that we in Colonial studies might address. The challenge of doing so is to avoid anachronistic thinking and facile, misleading comparisons. The challenge, in other words, is to be at once historically responsible and theoretically informed, that is, to act on the basis of what one knows and to speculate smartly about the latitudes and limits of the possible.

In this regard, the figure of Estevanico himself becomes emblematic. As he was portrayed by Cabeza de Vaca, and whether the "gentleman from Jerez de la Frontera" intended it or not, Estevanico is characterized in the narrative for acting and surviving by his wits. While Cabeza de Vaca foregrounded himself and his Castilian compatriots as acting on faith and behaving themselves with caution 
and reticence during the long years of the Texas sojourn and the trans-Texas-Mexico trek, he described Estevanico as the one who was sent out, alternately into the wilderness and into the crowds, playing the crucial and dangerous role of scout and mediator. Cabeza de Vaca (in Adorno and Pautz 1: 232, 233) wrote: "The black man always spoke to them and informed himself about the roads we wished to travel and the villages that there were and about other things that we wanted to know." ["El negro les hablava siempre y se informava de los caminos que queríamos ir y los pueblos que avía y de las cosas que queríamos saber."] It was Estevanico who had to act on the basis of what he knew (his experience, his "history") as well as on the basis of his smartest speculations (his best efforts at "theorizing"). The fact that he survived those seven and a half years testifies to his success in undertaking this double challenge. In transatlantic, tri-continental circumstances that cannot be reduced to dual arrangements, the double challenge posed by history and theory constitutes, for us as academics and in its broadest metaphorical sense, the "legacy of Estevanico."

\section{Notes}

1 For a full, up-to-date account of Estevanico's life based on primary sources, as well as a new Spanish and English translation of Cabeza de Vaca's 1542 Relación, see Adorno and Pautz 2:414-422 and 1:14291 , respectively.

2 See, below, the bibliographic entries for Panger, Parish, and Nieto Ventura.

3 Miller (165) writes: "But today, unlike the time of Memmi's youth, we see peoples who were once colonized now fully at ease in multiple languages, their own and the languages of their former colonizers. Mastering the language of the other is no longer seen as a cause for a 'cultural crisis.' Rather, it is regarded as a natural and necessary step for those who aspire to lead in their society." I do not agree that the problems of "colonial bilingualism" have been so easily transcended.

4 I selected for class reading just a few segments of el Inca Garcilaso's Comentarios reales: the opening section of the Primera parte, the chapters in Book One on the origins of the Incas and the establishment of Inca civilization, together with Garcilaso's protestations about the writing of history. From the Segunda parte, I prepared the "Prologue to the Indians, mestizos, and creoles... of Peru"["Prólogo a los indios, mestizos y criollos...del Perú"] and, from 
Book One, the narration that extends from the arrival of the Spanish in Peru through their execution of Atahualpa.

Garcilaso's Comentarios reales de los Incas [1609, 1616] is available in English translation as Royal Commentaries of the Incas and General History of Peru, Parts One and Two. Part One is available in paperback. See the bibliographic entries, below.

I followed El Inca Garcilaso with Felipe Guaman Poma's Nueva corónica y buen gobierno [1615-1616] account of the conquest of Peru (the "Conquista"segment of the work, pp. 370-437). The full digitized facsimile edition of the original manuscript is available on the website of the Royal Library of Copenhagen, http://www.kb.dk/elib/mss/poma/, which also includes related materials. An English translation of selections is available at http://www.mtp.dk/authors/adorno/. (Although often cited and recently anthologized, and despite its own claims, Christopher Dilke's English language Letter to a King is not a translation of the text but rather a highly interpretive adaptation based on Luis Bustios Gálvez's modern rewriting of Guaman Poma's original work.)

In addition to Memmi, the students also read selections from The Postcolonial Studies Reader: Stephen Slemon's "The Scramble for Post-colonialism," Anthony Appiah's "The Postcolonial and the Postmodern," and Homi Bhabha's "Signs Taken for Wonders." My objective was to help the students understand that, although written many centuries ago, El Inca Garcilaso's and Guaman Poma's works were remarkably modern and belonged to postcolonial discourse, insofar as "post-colonial," in Ashcroft's words (117) "does not means 'post independence,'or 'after colonialism,'for this would be to falsely ascribe an end to the colonial process. Post colonialism, rather, begins from the very first moment of colonial contact. It is the discourse of oppositionality which colonialism brings into being."

5 See Urioste's study of Guaman Poma's language.

6 The Royal Library's digital facsimile edition, http://www.kb.dk/en/nb/tema/poma/index.html, is a remarkable source for students's study of the drawings.

\section{Works cited}

Adorno, Rolena. "El Inca Garcilaso de la Vega 1539-1616." In Encyclopedia of Latin American Literature. Ed. Verity Smith. Chicago: Fitzroy Dearborn, 1997. 359-361. 
Adorno, Rolena and Patrick Charles Pautz. Álvar Núñez Cabeza de Vaca: His Account, His Life, and the Expedition of Pánfilo de Narváez. 3 vols. Lincoln and London: University of Nebraska Press, 1999.

Appiah, Kwame Anthony. "The Postcolonial and the Postmodern." In The Post-Colonial Studies Reader. Ed. Bill Ashcroft, Gareth Griffiths, and Helen Tiffin. London and New York: Routledge, 1995. 119-124.

Bhabha, Homi K. "Signs Taken for Wonders." In The Post-Colonial Studies Reader. Ed. Bill Ashcroft, Gareth Griffiths, and Helen Tiffin. London and New York: Routledge, 1995. 29-35.

Cornejo Polar, Antonio. "El comienzo de la heterogeneidad en las literaturas andinas: voz y letra en el 'diálogo' de Cajamarca." In Escribir en el aire. Lima: Horizonte, 1994. 25-89.

Garcilaso de la Vega, El Inca. Comentarios reales de los Incas. In Obras completas del Inca Garcilaso de la Vega. Ed. Carmelo Sáenz de Santa María. Biblioteca de Autores Españoles 133-135. 3 vols. Madrid: Atlas, 1960-1965.

---. Royal Commentaries of the Incas and General History of Peru, Parts One and Two, trans. Harold V. Livermore, foreword by Arnold J. Toynbee. Austin: University of Texas Press, 2 vols., 1966.

Guaman Poma de Ayala, Felipe. El primer nueva corónica y buen gobierno. Ed. John V. Murra y Rolena Adorno; traducciones del quechua de Jorge L. Urioste. 3 tomos. México: Siglo Veintiuno Editores, 1980.

---. El primer nueva corónica y buen gobierno [1615/1616]. Complete digital edition. Scholarly consultant: Rolena Adorno. Copenhagen, Royal Library, GkS 2232 4to (http://www.kb.dk/permalink/2006/poma/info/es/frontpage.htm)[was www.kb.dk/elib/mss/poma/].

Klegner, Deborah and Commire, Anne (Editors) Historic World Leaders. Detroit: Gale Research, 1994.

Kubayanda, Josephat Bekunuru. On Colonial//mperial Discourse and Contemporary Critical Theory. Working Papers Series. College Park, MD: Department of Spanish and Portuguese, University of Maryland, 1990. 
MacCormack, Sabine. "Atahualpa y el libro." Revista de Indias 48, no. 184 (1988): 693-714.

Memmi, Albert. The Colonizer and the Colonized. [1957]. Foreword by Jean-Paul Sartre. Trans. Howard Greenfield. Boston: Beacon Press, 1991.

Miller, Susan Gilson. "Afterword." In Albert Memmi, The Colonizer and the Colonized. [1957]. Foreword by Jean-Paul Sartre. Trans. Howard Greenfield. Boston: Beacon Press, 1991. 155-169.

Millones, Luis. Actores de altura: ensayos sobre el teatro popular andino. Lima: Editorial Horizonte, 1992.

Nieto Ventura, Miguel Ángel. Cabeza de Vaca: el mago blanco. Barcelona: Sociedad Estatal Quinto Centenario and Planeta-Agostini Editor, 1992.

Panger, Daniel. Black Ulysses. Athens, Ohio: Ohio University Press, 1982.

Parish, Helen Rand. Estevanico. New York: Viking Press, 1974.

Slemon, Stephen. "The Scramble for Post-colonialism." In The PostColonial Studies Reader. Ed. Bill Ashcroft, Gareth Griffiths, and Helen Tiffin. London and New York: Routledge, 1995. 45-52.

Titu Cussi Yupanqui, Diego de Castro. Ynstrucción del Ynga don Diego de Castro Titu Cussi Yupanqui para el muy ilustre señor el Licenciado Lope de García de Castro. [1570]. Ed. Luis Millones. Lima: El Virrey, 1985.

Urioste, Jorge L., "Estudio analítico del quechua en la Nueva corónica." In Guaman Poma xx-xxxi. 